Article

\title{
Sustainable Recycling of High-Strength Concrete as an Alternative to Natural Aggregates in Building Structures
}

\author{
Barbara Sadowska-Buraczewska ${ }^{1}$ (D) and Małgorzata Grzegorczyk-Frańczak ${ }^{2, *(D)}$ \\ 1 Department of Structural Engineering, Faculty of Civil Engineering and Environmental Sciences, \\ Bialystok University of Technology, 15-351 Bialystok, Poland; barbara.sadowska@pb.edu.pl \\ 2 Civil Engineering Laboratory, Faculty of Civil Engineering and Architecture, Lublin University of Technology, \\ 20-618 Lublin, Poland \\ * Correspondence: m.grzegorczyk@pollub.pl
}

check for updates

Citation: Sadowska-Buraczewska, B.; Grzegorczyk-Frańczak, M.

Sustainable Recycling of

High-Strength Concrete as an

Alternative to Natural Aggregates in Building Structures. Sustainability 2021, 13, 4286. https://doi.org/ $10.3390 /$ su13084286

Academic Editors: Jorge de Brito and Marcin K. Widomski

Received: 18 March 2021

Accepted: 9 April 2021

Published: 12 April 2021

Publisher's Note: MDPI stays neutral with regard to jurisdictional claims in published maps and institutional affiliations.

Copyright: (c) 2021 by the authors. Licensee MDPI, Basel, Switzerland. This article is an open access article distributed under the terms and conditions of the Creative Commons Attribution (CC BY) license (https:// creativecommons.org/licenses/by/ $4.0 /)$.

\begin{abstract}
The application of recycled coarse aggregates (RCA) in high-performance concrete (HPC) was analyzed in the article. In the paper, the behavior of HPC with coarse recycled aggregate and natural coarse aggregate (NCA) was compared. Short-term experiments were conducted, including concrete deformation, deflection, load bearing capacity, and cracking of beams. The analysis involved reinforced concrete T-beams made in $100 \%$ of RCA or NCA. The studies indicated that the beams with recycled aggregate are characterized by greater deflection and $7.6 \%$ lower load bearing capacity in comparison to the beams with NCA. Substitution of coarse natural aggregate with RCA reduced the compressive and tensile strengths by 20 and $26(\%)$, whereas and the modulus of elasticity was decreased by $15 \%$.
\end{abstract}

Keywords: recycled aggregates (RA); recycled coarse aggregates concrete (RCAC); high performance concrete (HPC); reinforced concrete beams

\section{Introduction}

One of the greatest problems connected with sustainable development is the depletion of global natural resources. The global construction industry uses over 40 billion tons of aggregates per year, with even up to 4 billion tons corresponding to Europe. It should be noted that up to $91 \%$ of aggregates used in Europe are of natural aggregates [1]. Along with the development of the construction industry, the amount of construction waste (i.e., concrete, masonry and ceramic rubble, plaster, wallpaper residues, adhesives, paints, door and window woodwork, and installation waste) systematically increases, and their storage is problematic [2]. Construction waste mainly originates from demolition and dismantling of unused concrete structures, road and railway construction, the destructive effects of natural disasters, as well as by-products from production plants [3]. According to the European statistics, in 2016 the construction wastes constituted over 36\% of total wastes generated in the EU [4]. Therefore, the possibility of using recycled aggregates (RA) becomes increasingly important. Such aggregate contributes to reduced exploitation of natural resources, costs of construction waste disposal as well as supports the sustainable development of the construction industry $[5,6]$.

The International Union of Laboratories and Experts in Construction Materials, Systems and Structures (RILEM) [7] distinguishes three types of recycled aggregates:

- $\quad$ Type I-aggregate from masonry rubble;

- $\quad$ Type II-aggregate from concrete rubble;

- $\quad$ Type III-aggregates comprising at least 80\% natural aggregates.

At present, recycled aggregate is most often utilized in road construction as a road base, sidewalk base, as well as pavement for squares and parking lots [8-11]. This is connected with certain limitations of the aggregate obtained from concrete. Numerous 
studies indicate that recycled aggregate is characterized by lower density and greater water absorptivity improvement [12-16]. According to Surendar et al. [17], water absorptivity increases along with the increase in the recycled aggregate substitution of natural aggregate. Moreover, recycled aggregate is characterized by greater absorptivity and increases the water demand, which may affect the hydration process [18]. The aggregate obtained from concrete rubble indicates lower mechanical strength than natural aggregates as well as greater susceptibility to abrasion and crushing value. Studies proved that the compressive strength of concrete decreases with the increasing degree of natural aggregate substitution with recycled aggregate [12-16,19].

The main issue with the aggregates from concrete rubble, is the double interfacial transition zone (ITZ) between the aggregate and the old adhered mortar as well as between the new and old ITZ. The old paste is porous and contains microcracks, which contributes to the increased absorptivity of the recycled aggregate [17]. Numerous studies prove that the content of old adhered mortar increases along with the aggregate crushing degree, which is connected with the technological production process [6]. Suryawanshi et al. [13] observed that there is a relationship between the fraction size of the recycled aggregate and the amount of the remaining adhered mortar. According to the authors, the amount of old adhered mortar encapsulating the aggregate increases as the aggregate size decreases. This is connected with the aggregate processing method. As the concrete is being crushed into finer aggregate, old mortar accumulates in the pores of fine aggregate [14].

These issues can be solved by using high strength recycled aggregates. Earlier studies [20] indicated that the concrete with recycled aggregate from crushed high performance concrete (HPC) has much more favorable properties compared with the concrete containing the aggregate from ordinary concretes. Adjukiewicz et al. [21] observed that high strength concretes can be obtained with $100 \%$ recycled coarse aggregate from the concretes characterized by the strength of $60 \mathrm{MPa}$. Gonzalez-Corominas et al. [22] observed an increase in the compressive strength resulting from the incorporation of aggregates from the concretes with the strength of $100 \mathrm{MPa}$. HPC comprises, i.a. microsilica, which reduces porosity and permeability of concrete [23-25]. Studies prove [26] that HPC with recycled aggregate achieves similar compressive strength to that of the concretes with natural aggregate.

The aim of the work was to analyze of the results of experimental studies on high strength recycled aggregate in high performance concretes (HPC). Short-term experiments were conducted, including elastic modulus, deflection, load-bearing capacity, and cracks in the beam under increasing load.

\section{Materials and Methods}

\subsection{Materials}

Two concrete recipes were devised:

- NCAC—high performance concrete with natural aggregate

- $\quad$ RCAC—recycled coarse HPC aggregate concrete.

Detailed composition of concretes is presented in Table 1.

Table 1. Composition of concrete $\left(\mathrm{kg} / \mathrm{m}^{3}\right)$.

\begin{tabular}{ccc}
\hline Component & NCA & RCA \\
\hline Portland cement CEM I 52.5 R & 450 & 450 \\
Sand 0-2.0 mm & 630 & 630 \\
Natural coarse aggregate-basalt 2.0-8.0 mm & 1070 & - \\
Recycled coarse aggregate-concrete 2.0-8.0 mm & - & 1070 \\
Silica fume & 45 & 45 \\
Superplasticizer & 8.1 & 8.1 \\
Water & 119 & 119 \\
\hline
\end{tabular}

CEM I 52.5 R Portland cement (Grupa Ożarów S.A., Poland) was used as the main binder. The cement meets all the requirements in line with the EN-197-1:2012 [27] and 
PN-B-19707:2013 [28] standards. The cement properties are presented in Table 2. Silica fume with the density of $2.40 \mathrm{~g} / \mathrm{cm}^{3}$ was used as a pozzolanic additive to the binder in the amount of $10 \%(w / w)$, in line with the requirements of the PN-EN 13263-1:2005 standard [29]. The $\mathrm{w} / \mathrm{c}$ (water/cement) ratio in both cases amounted to 0.26. In turn, the $\mathrm{w} / \mathrm{b}$ (water/binder) ratio equaled 0.24 .

Table 2. Properties of CEM I 52.5 R [30].

\begin{tabular}{ccc}
\hline Parameters & Unit & \\
\hline Specific surface & $\left(\mathrm{cm}^{2} / \mathrm{g}\right)$ & 4530 \\
Loss on ignition by mass cement & $(\%)$ & 3.10 \\
Insoluble parts & $(\%)$ & 0.64 \\
$\mathrm{SO}_{3}$ content & $(\%)$ & 2.87 \\
$\mathrm{Cl}_{\text {content }}$ & $(\%)$ & 0.05 \\
$\mathrm{Na}_{2} \mathrm{O}_{\text {eq }}$ content & $(\%)$ & 0.65 \\
Initial setting time & $(\mathrm{min})$ & 157 \\
Compressive strength & & 35.80 \\
after 2 days & $(\mathrm{MPa})$ & 63.70 \\
after 28 days & $(\mathrm{mm})$ & 0.20 \\
Volume stability & &
\end{tabular}

The chemical analysis of silica fume is presented in Table 3. The data has been taken from a paper previously published by one of the authors [31].

Table 3. Chemical composition of the silica fume [31].

\begin{tabular}{ccccccccccc}
\hline Compositions & & $\mathrm{SiO}_{\mathbf{2}}$ & $\mathbf{A l}_{\mathbf{2}} \mathbf{O}_{\mathbf{3}}$ & $\mathrm{Fe}_{\mathbf{2}} \mathrm{O}_{\mathbf{3}}$ & $\mathrm{CaO}$ & $\mathbf{S O}_{3}$ & $\mathbf{N a}_{\mathbf{2}} \mathbf{O}_{3}$ & $\mathbf{K}_{\mathbf{2}} \mathbf{O}$ & Other Alkali Compounds \\
\hline Unit & $(\%)$ & 90 & 0.4 & 0.4 & 1.6 & 0.4 & 0.5 & 2.2 & 1.9 & \\
\hline
\end{tabular}

Natural quartz sand with the density of $0.65 \mathrm{~g} / \mathrm{cm}^{3}$ and fraction size of $0.0-2.0 \mathrm{~mm}$ were employed as natural fine aggregate (NFA). In NCA, natural basalt (fraction size 2.0-8.0 $\mathrm{mm}$ ) was used as coarse aggregate; it was characterized by the following parameters: specific density $-2.93 \mathrm{~g} / \mathrm{cm}^{3}$, bulk density $-2.92 \mathrm{~g} / \mathrm{cm}^{3}$, absorptivity $-0.31 \%$, compressive strength $-280 \mathrm{MPa}$, frost resistance $-\mathrm{F}_{2}$.

Recycled aggregate (fraction size 2.0-8.0) with the following parameters: specific density $-2.80 \mathrm{~g} / \mathrm{cm}^{3}$, bulk density $-2.60 \mathrm{~g} / \mathrm{cm}^{3}$, absorptivity $-0.78 \%$, compressive strength $-155 \mathrm{MPa}$, frost resistance $-\mathrm{F}_{2}$, was obtained through crushing of HPC characterized by the compressive strength of 155 MPA. A jaw crusher with adjustable grinding degree was used for this purpose. Then, the aggregate was passed through sieves, obtaining the fraction with the size of $2.0-4.0 \mathrm{~mm}$ (Figure 1a) and $4.0-8.0 \mathrm{~mm}$ (Figure 1b) fractions. The chemical composition of the aggregates is presented in Table 4 . The data have been taken from a paper published by one of the authors [30].

Natural coarse aggregate and recycled aggregate were added to the concrete in the following way:

- $33 \%$ mass of coarse aggregate- $2.0-4.0 \mathrm{~mm}$ fraction size;

- $67 \%$ mass of coarse aggregate- $4.0-8.0 \mathrm{~mm}$ fraction size.

Waste aggregate was classified as RCAC II (aggregate from concrete rubble), according to the RILEM classification [7].

In order to reduce the mixing water, new generation polycarboxylic superplasticizer with the density of $1.08 \mathrm{~g} / \mathrm{cm}^{3}$ and $\mathrm{pH} 4.0$ was used in the amount of $1.8 \%$ cement mass $(w / w)$ [31]. Owing to the surface absorption phenomenon and the effect of spatial particle separation acting upon cement grains, the additive accelerates curing, as well as improves the early strength and the workability of fresh mixture [31]. 


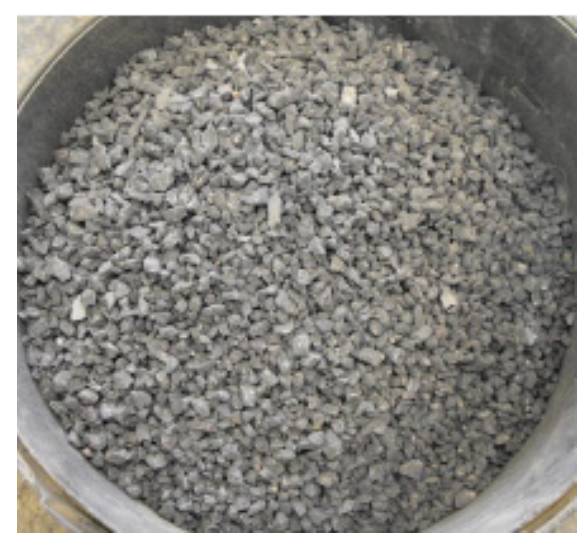

(a)

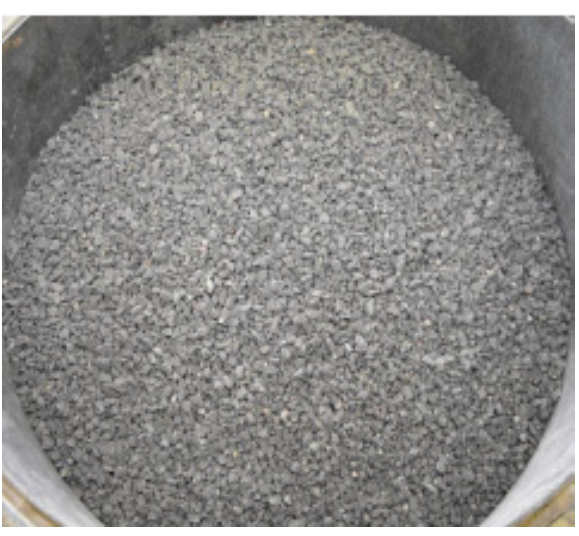

(b)

Figure 1. Recycled high performance concrete (HPC) aggregate: (a) 4.0-8.0 mm fraction; (b) 2.0$4.0 \mathrm{~mm}$ fraction.

Table 4. Chemical composition of the aggregates (\%) [30].

\begin{tabular}{ccccc}
\hline Compositions & Unit & NFA & NCA & RCA \\
\hline $\mathrm{SiO}_{2}$ & $(\%)$ & 95.2 & 48.5 & 26.6 \\
$\mathrm{Al}_{2} \mathrm{O}_{3}$ & $(\%)$ & 2.0 & 13.8 & 23.2 \\
$\mathrm{FeO}$ & $(\%)$ & - & 10.5 & 2.4 \\
$\mathrm{Fe}_{2} \mathrm{O}_{3}$ & $(\%)$ & 0.6 & - & - \\
$\mathrm{CaO}$ & $(\%)$ & 0.45 & 10.0 & 35.3 \\
$\mathrm{MgO}$ & $(\%)$ & - & 12.2 & 2.5 \\
$\mathrm{TiO}_{2}$ & $(\%)$ & - & 0.9 & 0.3 \\
$\mathrm{~K}_{2} \mathrm{O}$ & $(\%)$ & - & 0.1 & 3.2 \\
Other alkali compounds & $(\%)$ & - & 4.0 & 6.5 \\
\hline
\end{tabular}

\subsection{Methods}

The concrete samples were prepared in line with PN-EN 12390-1:2013-03 [32] and PN-EN 12390-2:2019-07 [33]. The samples were permanently marked and stored at a temperature of $(20 \pm 5){ }^{\circ} \mathrm{C}$. Directly after the preparation of samples, they were tightly covered with foil protecting against the evaporation of water from their surface. After two days, the samples were demolded and kept in water at a temperature of $(20 \pm 2){ }^{\circ} \mathrm{C}$ and relative air humidity $\geq 95 \%$ until the experiments were conducted.

The compressive strength was determined on 3 cubic samples with edge length of $100 \mathrm{~mm}$, according to PN-EN 12390-3:2019-07 [34]. The test was performed after 7, 14, and 28 days of curing in water at a temperature of $(20 \pm 2){ }^{\circ} \mathrm{C}$.

Tensile test during four-point bending after 28 days of curing was determined on 3 cuboid samples with the dimensions of $100 \times 100 \times 400 \mathrm{~mm}$, in line with PN-EN 123905:2019-08 [35].

Secant modulus of elasticity was determined in accordance with the PN-EN 1239013:2014-02 standard [36] on cylindrical samples with the diameter of $150 \mathrm{~mm}$ and height of $300 \mathrm{~mm}$. The measurements of dislocations were performed using an extensometer with the base of $100 \mathrm{~mm}$. The modulus of elasticity test was preceded by determining the compressive strength of cylindrical samples, in accordance with PN-EN 12390-3:201907 [34], in order to determine the upper limit of compressive force.

The modulus of elasticity of concrete was calculated based on the formula below:

$$
E_{c m}=\frac{\sigma_{G}-\sigma_{D}}{\left(\frac{\varepsilon_{G}^{\prime}+\varepsilon^{\prime \prime} G+\varepsilon^{\prime \prime \prime} G}{3}\right)-\left(\frac{\varepsilon_{D}^{\prime}+\varepsilon^{\prime \prime} D+\varepsilon^{\prime \prime \prime} D}{3}\right)}(\mathrm{GPa})
$$

where 
$\varepsilon_{G}$-deformation at the upper limit of the force, which is $250 \mathrm{kN}$ (this value is governed by the maximum pressure force that can be generated by the operated testing machine);

$\varepsilon_{D}$-deformation at the lower limit of the force, amounting to $20 \mathrm{kN}$ (this value is governed by the minimum pressure force causing first visible deflections);

$\sigma_{G}$-stresses at the upper limit of the force;

$\sigma_{D}$-stresses at the lower limit of the force.

Measurement of deflections was performed on 3 reinforced concrete T-beams with the dimensions and static diagram shown in Figure 2.

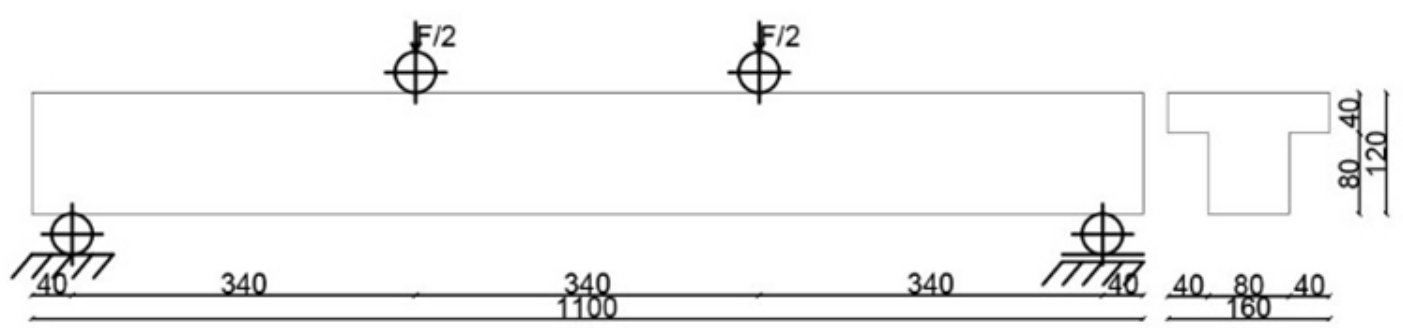

Figure 2. Static diagram of the reinforced concrete T-beam ( $\mathrm{mm})$.

The beams were reinforced from the top and bottom with two $\varnothing 8 \mathrm{~mm}$ bars, whereas rebar stirrups were made of smooth steel with the diameter of $\varnothing 3 \mathrm{~mm}$. The main reinforcement was made of B500 steel with the yield strength of $R e=500 \mathrm{MPa}$, in line with Technical Approval AT-15-4648/2006 [37]. Steel spacers welded to the bottom reinforcement ensure $1 \mathrm{~cm}$ cover of the lower reinforcement. The reinforcement scheme was identical for all beams. The measurements of deflections were performed using dislocation sensors with the approximate accuracy of the measurement equal to $0.001 \mathrm{~mm}$, placed in three spots: above the left support, above the right support and in the middle of the beam span. The sensors were reset after applying the load of $5 \mathrm{kN}$. The specimens were subjected to load until failure at a loading rate of $50 \mathrm{~N} / \mathrm{s}$. The measurements were performed after increasing the load by $5 \mathrm{kN}$ increments until beam destruction. The reinforcement scheme of the beam is presented in Figure 3.

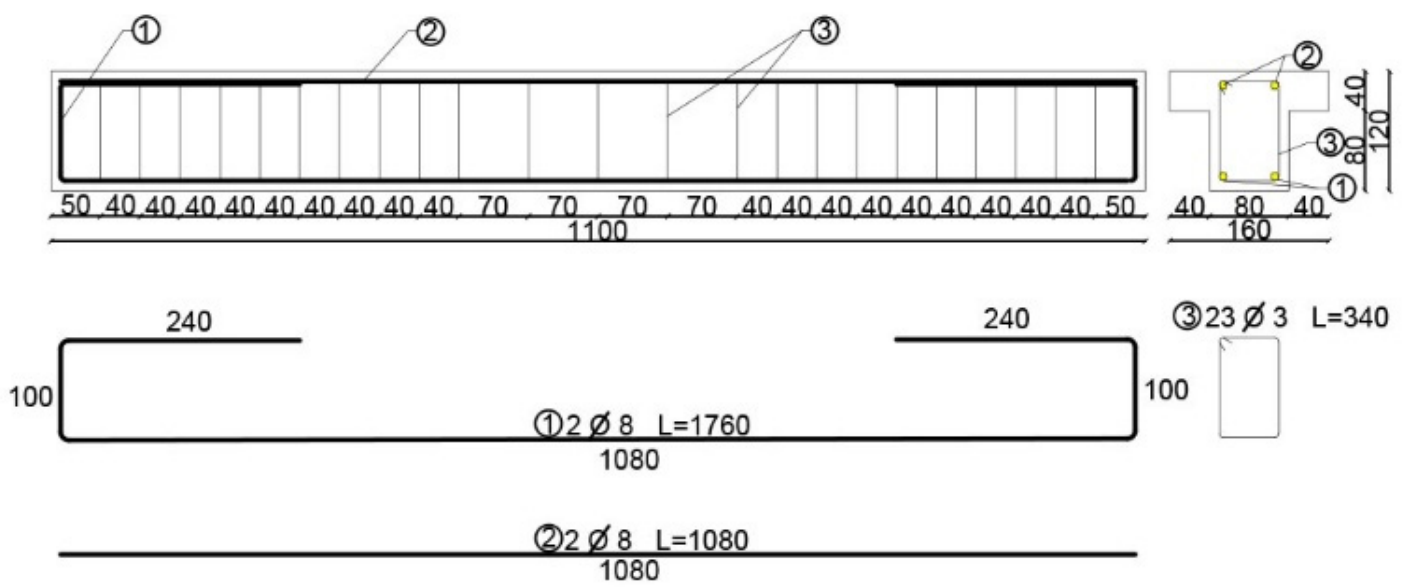

Figure 3. Reinforcement scheme of T-beam (mm).

The flexural bending capacity was determined on reinforced concrete T-beams with the dimensions presented in Figure 2 as well as reinforcement shown in Figure 3. The tests were conducted until the beams were destroyed.

The cracks tests were performed on T-beams with the dimensions shown in Figure 3. The loading was gradually increased in $5 \mathrm{kN}$ increments. In order to facilitate the observation of the appearing of cracks, the beam surface was painted white. The appearing cracks or development of the existing ones were marked on the beam surface. 


\section{Results and Discussion}

The compressive strength values, measured after three periods of curing $(7,14,28$ days $)$ as well as tensile bending strength after 28 days of curing are presented in Table 5, as well as Figures 4 and 5 .

Table 5. Compressive strength of concretes with natural and recycled aggregates.

\begin{tabular}{ccccc}
\hline & $\begin{array}{c}\text { Compressive } \\
\text { Strength } \mathbf{f}_{\mathrm{cm}} \\
\text { after 7 Days }\end{array}$ & $\begin{array}{c}\text { Compressive } \\
\text { Strength } \mathbf{f}_{\mathbf{c m}} \\
\text { after 14 Days }\end{array}$ & $\begin{array}{c}\text { Compressive } \\
\text { Strength } \mathbf{f}_{\mathrm{cm}} \\
\text { after 28 Days }\end{array}$ & $\begin{array}{c}\text { Flexural } \\
\text { Strength } \mathbf{f}_{\mathrm{fm}} \\
\text { after 28 Days }\end{array}$ \\
\hline $\mathrm{(MPa)}$ & $\mathbf{( M P a )}$ & $\mathbf{( M P a )}$ & $\mathbf{( M P a )}$ \\
\hline $\mathrm{NCAC}$ & 106.7 & 117.4 & 127.2 & 9.2 \\
$\mathrm{SD}$ & 4.21 & 2.44 & 1.23 & 0.90 \\
$\mathrm{CV}$ & 3.94 & 2.08 & 0.97 & 10.34 \\
$\mathrm{RCAC}$ & 90.7 & 95.6 & 101.4 & 6.8 \\
$\mathrm{SD}$ & 1.61 & 1.05 & 3.82 & 0.67 \\
$\mathrm{CV}$ & 1.77 & 1.10 & 3.77 & 9.74 \\
\hline
\end{tabular}

SD—standard deviation; CV—coefficient of variation, (\%).

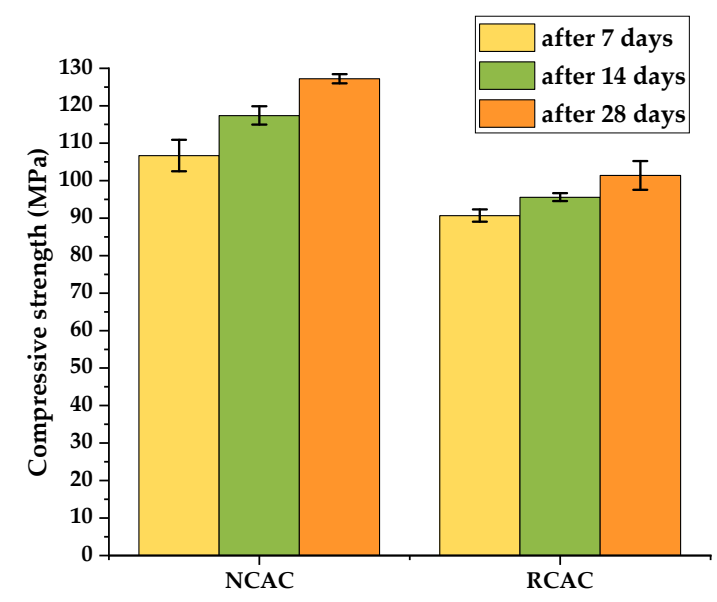

Figure 4. Compressive strength of concretes.

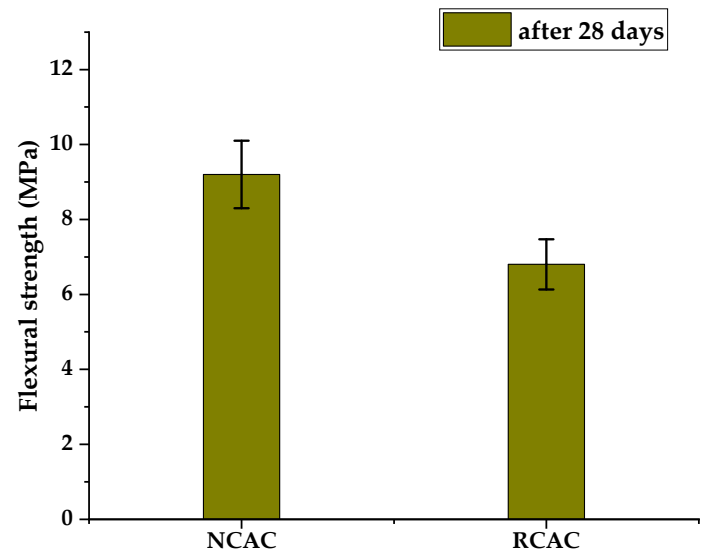

Figure 5. Flexural strength of concretes.

The results indicate that the concrete made of recycled aggregate is characterized by lower compressive strength in each of the curing periods (Figure 4) and $26 \%$ lower flexural strength after 28 days (Figure 5). It was also observed that the percentage of compressive strength reduction decreased progressively with time. While the early strength of concrete with recycled concrete aggregate after 7 days was $15 \%$ lower in comparison to the concrete 
with natural aggregate, after 28 days of curing, this difference increased to $20 \%$. The concretes with recycled aggregate were also characterized by greater compressive strength increase after 7-28 days, compared to NCAC.

A reduction in the compressive strength of the concrete containing recycled aggregate has already been described in numerous publications [38-42]. This phenomenon is connected with the presence of old cement mortar and microcracks appearing during the crushing of concrete [38]. The concrete with recycled aggregate contains double interfacial transition zones (ITZ) between the old adhered mortar and new ITZ [39]. Due to the porosity of the old adhered mortar, ITZ between the old and new mortar is characterized by low adhesion and high water absorption [40]. As a result, the concrete with recycled aggregate is characterized by lower strength than the concrete with natural aggregate. Moreover, recycled aggregate with higher capillary absorption compared to natural aggregate results in the supply of insufficient amount of water required for the hydration of cement particles, thus forming weaker C-S-H phase $[41,42]$. The studies on the HPC with recycled aggregate were conducted by $\mathrm{Tu}$ et al. [41]. Their results show that the samples containing solely recycled aggregate achieve 20-30 (\%) lower compressive strength compared with the HPC comprising mixed aggregate (recycled coarse aggregate and natural fine aggregate) during all curing periods. Mohammed et al. [43] noted that the concretes with $\mathrm{f}_{\mathrm{cm}, 28}=70 \mathrm{MPa}$, reached $14 \%$ lower compressive strength when the natural aggregate was completely substituted with recycled aggregate and 3\% lower when the substitution amounted to $50 \%$. The concretes with recycled aggregate also achieved lower flexural strength than the concrete with recycled aggregate. The authors [43] also observed a reduction in flexural strength of 18 and 5 (\%) at 50 and 100 (\%) aggregate substitution, respectively, compared to the reference concrete.

Moreover, Andreu et al. [26] observed that HPC with recycled aggregate achieved similar or higher tensile bending strength compared to the concrete with natural aggregate. Complete substitution of natural aggregate with the recycled aggregate obtained from the concrete with the strength of $40 \mathrm{MPa}$ reduced the flexural strength by about $20 \%$. In turn, the application of concrete aggregate with higher strength $(60,100 \mathrm{MPa})$ improved the tensile strength in bending test by $20 \%$ or enabled to achieve a comparable result to the reference concrete, respectively.

Despite the lower mechanical properties of RCAC compared to the high-strength concretes with high strength, made of NCA, the concretes with recycled aggregate were characterized by greater compressive strength values, reaching approximately $100 \mathrm{MPa}$. Thus, higher strength parameters can be achieved by increasing the designed compressive strength.

The properties of concrete, out of which the aggregate is obtained, have significant influence on the mechanical properties of new concrete [26]. Therefore, the concrete with the recycled aggregate obtained from high-strength materials also achieved high strength properties. Poon et al. [44] compared the properties of the recycled aggregates obtained from normal-strength concretes (NPC) and HPC. It turned out that the porosity of the HPC aggregates was less than half the value exhibited by the aggregates from NPC. The Mercury Intrusion Porosimetry (MIP) analyses indicated the sizes of pores in the HPC aggregates to be lower than $0.1 \mu \mathrm{m}$, whereas the pores in the aggregates from ordinary concrete reached less than $1 \mu \mathrm{m}$. Smaller pore distribution in the HPC aggregates can be attributed to the presence of pozzolanic additives in old concrete matrix, which improved the matrix-aggregate ITZ. The HPC aggregate is characterized by dense ITZ with low total pore volume compared to normal-strength concretes.

The strength tests [44] indicated that the concrete with RCA from ordinary concrete reached 20 and 20.5 (\%) lower compressive strength after 7 and 28 days of curing, respectively, compared to the concrete with HPC aggregate. Moreover, the compressive strength of the concretes with the RCA-HPC aggregate following 28 days of curing was only $6.8 \%$ lower than the concrete with natural aggregate. Kou et al. [45] showed that the compressive strength of HPC with recycled aggregate from the concretes characterized 
by compressive strength of 80-100 (MPa), achieved $65 \mathrm{MPa}$. In addition, the achieved strength was comparable to the strength of the concretes with natural aggregate. According to Gonzales-Corominas et al. [22], the compressive strength in the early curing period is dependent on the amount of free water, rather than the quality of aggregate. The recycled HPC aggregate with moderate moisture content absorbs the entire free water, lowering the initial $\mathrm{w} / \mathrm{c}$ ratio in ITZ during the early hydration process. This leads to the release of water and self-hardening in the later period and filling the ITZ with the newly created hydrates. As a result, the cement-aggregate bonding improves [22];

The concrete strength largely depends on the mortar-aggregate ITZ [26]. ITZ can be improved through the application of silica fume, which—owing to its thickening abilitiesincreases the density of ITZ [46,47]. Corinaldesi et al. [48] showed that the concrete with recycled aggregate and $10 \%$ silica fume addition reached $25 \%$ and $38 \%$ greater compressive strength after 28 days of curing, than the concrete with natural aggregate and the concrete with recycled aggregate without additives, respectively. Authors [47] observed that the recycled aggregates containing calcium hydroxide improve the pozzolanic properties of silica fume and fly ash. Interestingly, the concretes with silica fume reached $14 \%$ higher modulus of elasticity compared with the reference concrete.

Table 6 presents the mean values of modulus of elasticity for the cylindrical samples with known strength values.

Table 6. Modulus of elasticity values of concrete measured on cylindrical samples with the given compressive strength.

\begin{tabular}{ccc}
\hline & Compressive Strength $\mathbf{f}_{\mathbf{c m}}$ after 28 Days & Modulus of Elasticity $\mathbf{E}_{\mathbf{c m}, \mathbf{2 8}}$ \\
\hline NCAC & $\mathbf{( M P a )}$ & $\mathbf{( G P a )}$ \\
SD & 77.1 & 59.34 \\
CV & 2.57 & 1.23 \\
RCAC & 3.33 & 2.07 \\
SD & 63.5 & 50.19 \\
CV & 4.03 & 1.15 \\
\hline
\end{tabular}

SD—standard deviation, CV—coefficient of variation, (\%).

The concretes made from recycled aggregate were characterized by $15 \%$ lower modulus of elasticity compared to the concretes made of natural aggregate. Figure 6 presents the samples during the elastic modulus $\mathrm{E}_{\mathrm{cm}, 28}$ test.

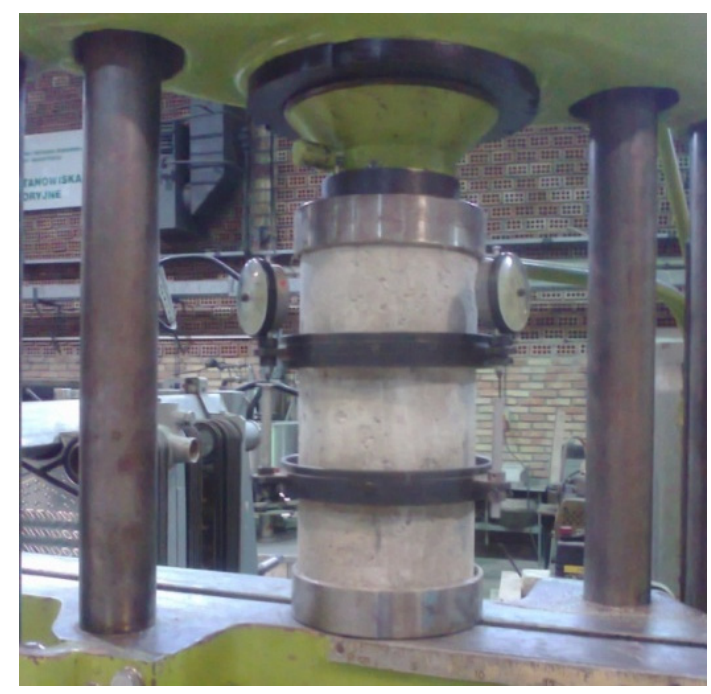

Figure 6. HPC during the elastic modulus test. 
This is confirmed in the studies by Wagih et al. [49], where $100 \%$ substitution of natural aggregate with recycled aggregate reduced the modulus of elasticity by $15 \%$ compared to the reference concretes. The authors of the paper noticed a beneficial influence of silica fume application on the elastic modulus increase, which improves the ITZ between the old adhered mortar and new mortar, acting as microfiller. The silica fume addition in the concretes with $100 \%$ recycled aggregate increased $\mathrm{E}_{\mathrm{cm}, 28}$ by $17 \%$ compared to the concrete without additive. The studies by Andreu et al. [26] showed that all concretes containing the recycled aggregate obtained from concretes of varying strength $(40,60$, and $100 \mathrm{MPa})$ were characterized by lower modulus of elasticity compared to the concrete with natural aggregate. Nevertheless, it should be noted that the concretes with recycled aggregate obtained modulus of elasticity in the range of 37.15-48.54 GPa, which is relatively high. Moreover, the authors [26] observed that the modulus of elasticity increases along with the strength of concrete, from which the aggregate was obtained. While the concretes made of the aggregate obtained from the $40 \mathrm{MPa}$ strength concrete were characterized by $26.3 \%$ lower elastic modulus than the reference concrete, the concretes with HPC aggregate $(100 \mathrm{MPa})$ reached the value which was only $3.7 \%$ lower than conventional concrete. According to Neville [50] the modulus of elasticity of concrete largely depends on the modulus of aggregate forming the concrete. In turn, Andreu et al. [26] observed that the modulus of elasticity strictly depends on the density of the material. Since the concretes with recycled aggregate are characterized by lower density; thus, the modulus of elasticity is lower than that of the concrete with natural aggregate [51]. In the above-mentioned studies, the concretes with greater compressive strength were characterized by higher modulus of elasticity. The correlations between elastic modulus and compressive strength are presented in Figure 7.

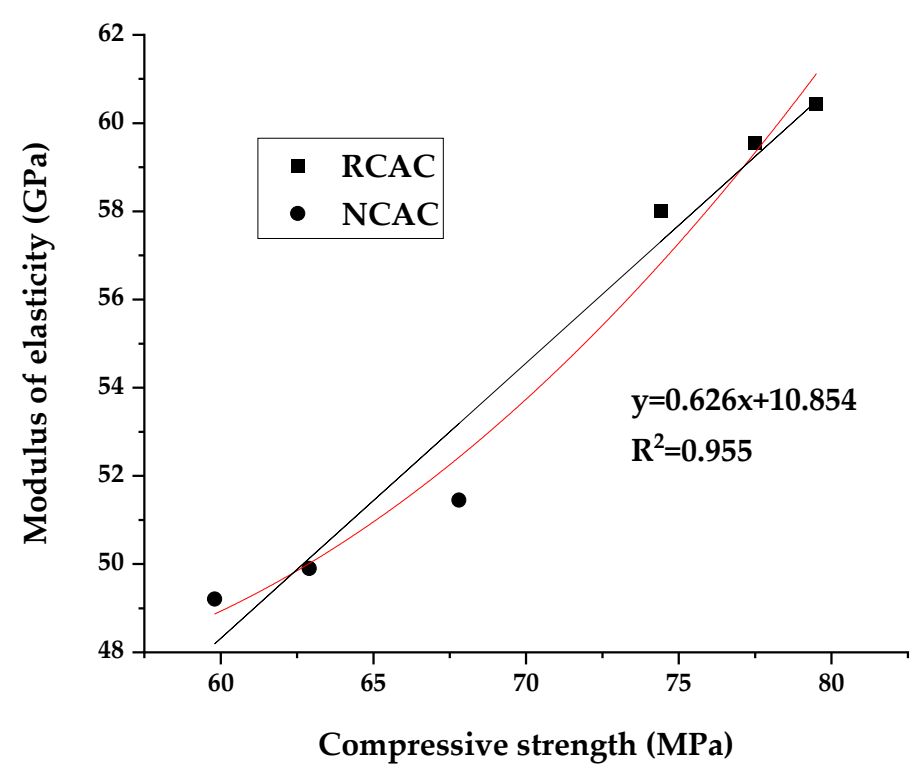

Figure 7. Dependence of elastic modulus $\mathrm{E}_{\mathrm{cm}, 28}$ on the compressive strength of concrete.

The graph clearly shows close correlation between the modulus of elasticity and the compressive strength of concrete. This is also confirmed by the previous studies conducted by the authors [30]. Similar conclusions were also drawn by Góra et al. [52]. The authors also emphasize the influence of aggregate crushing resistance on the modulus of elasticity of concrete. The concretes containing the aggregate with low crushing resistance had lower moduli of elasticity. Since recycled aggregates are characterized by low crushing resistance [12-16], the concretes produced using these aggregates have lower modulus of elasticity.

The values of deflections of the beams in the middle of the span are show in Table 7 and Figure 8. 
Table 7. The average deflections of the beams in the middle of the span depending on the applied load.

\begin{tabular}{|c|c|c|c|c|c|c|c|c|c|c|c|c|}
\hline \multicolumn{2}{|c|}{ Force F (kN) } & 0 & 5 & 10 & 15 & 20 & 25 & 30 & 35 & 40 & 45 & 50 \\
\hline \multirow{6}{*}{$\begin{array}{c}\text { Beam } \\
\text { deflection } \\
(\mathrm{mm})\end{array}$} & NCAC T-beam & 0 & 0.01 & 0.11 & 0.42 & 0.98 & 1.52 & 2.02 & 2.56 & 3.05 & 3.67 & 11.23 \\
\hline & SD & 0 & 0 & 0.01 & 0.01 & 0.01 & 0.01 & 0.02 & 0.02 & 0.02 & 0.02 & 0.02 \\
\hline & $\mathrm{CV}$ & 0 & 10.83 & 5.09 & 1.20 & 0.62 & 0.38 & 1.03 & 0.60 & 0.50 & 0.54 & 0.14 \\
\hline & RCAC T-beam & 0 & 0.17 & 0.39 & 0.73 & 1.10 & 1.88 & 2.16 & 2.76 & 3.14 & 9.08 & - \\
\hline & $\mathrm{SD}$ & 0 & 0.01 & 0.01 & 0.02 & 0.01 & 0.01 & 0.02 & 0.02 & 0.01 & 0.01 & - \\
\hline & $\mathrm{CV}$ & 0 & 3.33 & 1.49 & 2.08 & 0.52 & 0.53 & 0.71 & 0.72 & 0.18 & 0.11 & - \\
\hline
\end{tabular}

SD—standard deviation. CV—coefficient of variation, $(\%)$.

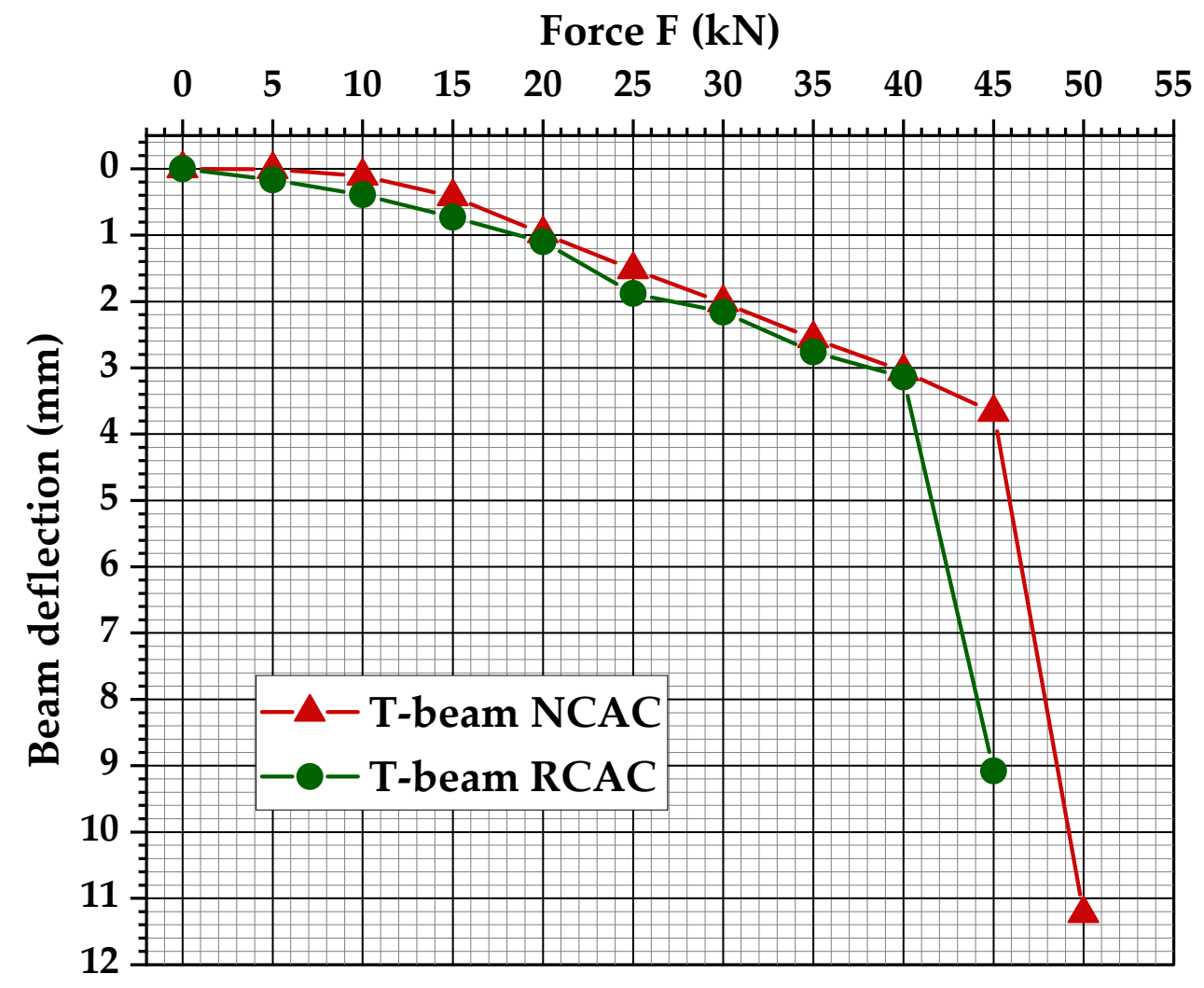

Figure 8. The average deflections of the beams in the middle of the span depending on the applied load.

The results of studies indicate that reinforced concrete made of natural aggregate shows smaller deflection compared to the concrete containing recycled aggregate. In case of the applied load of $45 \mathrm{kN}$, this value is almost 2.5-fold lower than RCAC. The greatest RCAC beam deflection, amounting to $9.08 \mathrm{~mm}$, was noted after applying the load of $45 \mathrm{kN}$; in turn, the beam with natural aggregate was loaded with $50 \mathrm{kN}$, achieving the deflection of $11.23 \mathrm{~mm}$. Figure 9 represents a reinforced concrete T-beam during the bending test.

Observations of the deflections during the bending test were also conducted by Khan et al. [53]. The studies conducted by the authors confirmed that the reinforced beams with recycled aggregate content of $30 \%$ of total coarse aggregate as well as fine natural aggregate exhibited twice greater deflection, compared to the beams made of natural aggregate. 


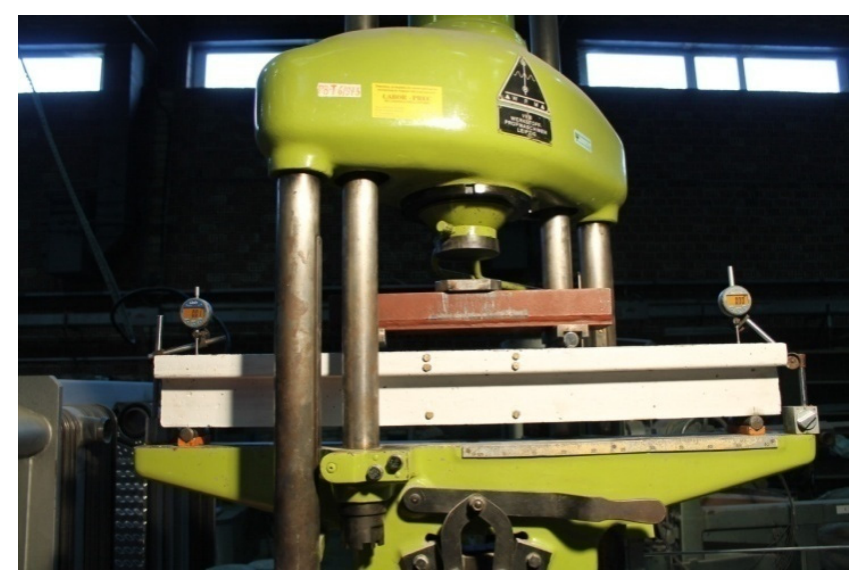

Figure 9. Reinforced concrete T-beam during the 4-point bending test.

Lapko et al. [54,55] observed that concrete beams containing RCA crack faster and are characterized by greater deflections compared to the beams made of natural aggregate. While the considered beams exhibited comparable deflections in the tension zone, the deflections in the compression zone of the beams with recycled aggregate were $45 \%$ greater, compared to the concretes with natural aggregate. The authors also observed a similar destruction mechanism in all beams, regardless of the type of aggregate, resulting from plastification of reinforcement in the tension zone.

The load bearing capacity of our T-beam was tested until destruction occurred. All beams, based on natural aggregates and high strength recycled aggregates, were destroyed through plastification of reinforcement in the tension zone. Table 8 presents the values of rupture force and breaking moments of T-beams.

Table 8. Mean values of rupture force and breaking moments of T-beams.

\begin{tabular}{ccc}
\hline & Rupture Force $\boldsymbol{F}$ & Breaking Moment $\boldsymbol{M}_{\boldsymbol{S} \boldsymbol{d}}$ \\
\hline NCACT- beam & $\mathbf{( k N )}$ & $\mathbf{( k N m )}$ \\
SD & 54.0 & 9.00 \\
CV & 1.00 & 0.17 \\
RCACT- beam & 1.85 & 1.83 \\
SD & 49.9 & 8.32 \\
CV & 1.15 & 0.19 \\
\end{tabular}

SD—standard deviation. CV-coefficient of variation, $(\%)$.

The studies indicate that the strength of reinforced RCAC T-beam, despite similar values, is $7.6 \%$ lower compared to the beam made of natural aggregate. A reduction in the load bearing capacity of the reinforced concrete beams following the substitution of natural aggregate with recycled aggregate was confirmed in other studies [54-57]. According to Arezoumandi et al. [58] the lower breaking moment of the concrete with recycled aggregate is caused by double ITZ in RAC and the related zone porosity as well as numerous microcracks in the aggregate occurring in the course of recycled aggregate processing.

Saara-Paz et al. [59] observed a decrease in the bending moment value along with the increasing substitution of natural aggregate with recycled one in the concretes with the w/c ratio equal to 0.65 and 0.50 . Complete natural aggregate substitution in the concretes with $\mathrm{w} / \mathrm{c}=0.65$ reduced the bending moment by $34 \%$, whereas the same amount of substitution in the concretes with lower $\mathrm{w} / \mathrm{c}$ decreased the bending moment by $28 \%$, compared to the concrete with natural aggregate.

According to Xiao et al. [60], the load bearing capacity of a RA beam results from the tensile reinforcement and compressed zone dependent on often random compressive strength of the concrete with the recycled aggregate. The authors' statistical study, showed 
that recycled aggregate with non-uniform quality increases the scatter of the concrete compressive strength results. Mukherjee et al. [61] while analyzing the statistical strength parameters of concrete made of recycled aggregate, noticed that the coefficient of variation of the compressive strength is $30 \%$ higher in the case of recycled aggregates compared to the concrete made of natural aggregates.

Fahmy et al. [62] investigated reinforcement concrete beams with different natural aggregate substitution degree. The studies showed that the reinforcement concrete beams with $25 \%$ substitution of natural coarse aggregate with recycled one reached the load bearing capacity comparable to the reference concrete. It should be noted that increasing the substitution of natural coarse aggregate with recycled aggregate to $50 \%$ improved the tensile load bearing capacity by $11.4 \%$. According to the authors, the increased tensile load bearing capacity was caused by improved maximum load. As a result, the yield strength of the beam with recycled aggregate increased by $13.5 \%$. The authors [62] drew attention to the fact that despite a similar crack morphology of the beam with 50\% RCA to the reference beam, the beam with recycled aggregate exhibited a lower number of cracks.

In our testing, despite a lower breaking moment in the concretes with recycled aggregate, all beams were characterized by the same destruction mechanism. Figure 10 presents the dependence of the applied load on the crack width in the investigated beams.

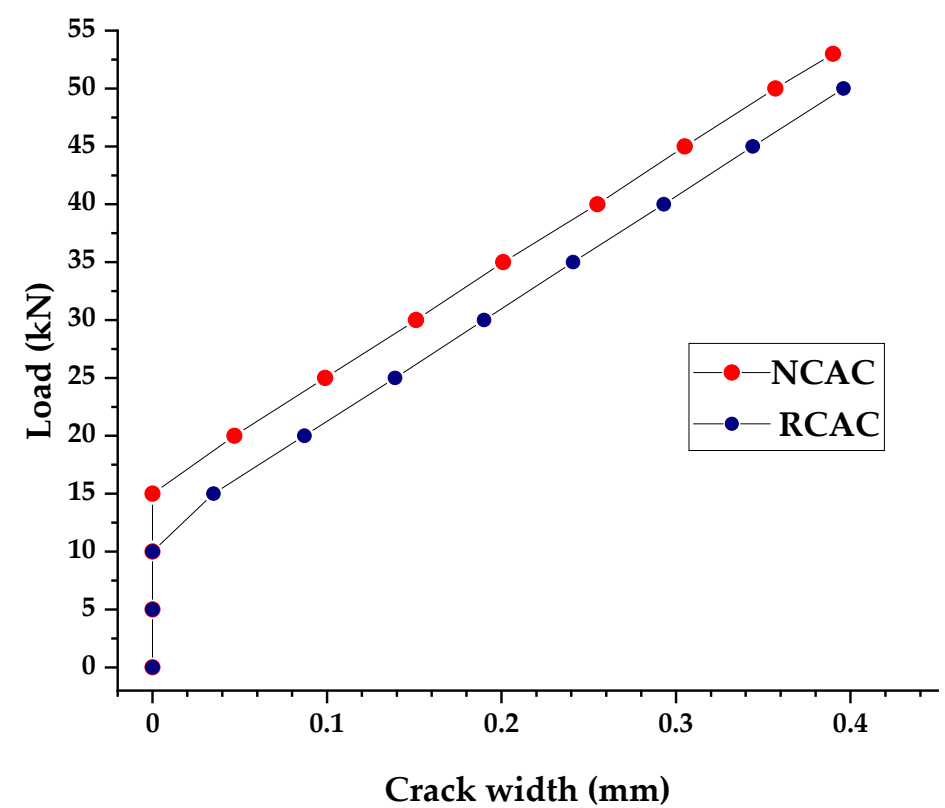

Figure 10. Load versus crack width.

The cracks on all beams had a similar appearance. The first perpendicular cracks were observed at the load of $15 \mathrm{kN}$. They occurred in the middle zone, in the area of constant bending moment. Due to a very small opening of the cracks at this load, it seems that only the surface lime layer was cracked. Initially, the image of diagonal cracks was similar to that of perpendicular cracks, with similar opening values and high inclination angles. A substantial increase in the influence of diagonal cracks on the whole cracking image occurred under the load of $35 \mathrm{kN}$. They started in the zone between the area of applied forces and supports, and then propagated in the direction of point applied forces. Figure 11 shows crack shaping and development in the test samples. 


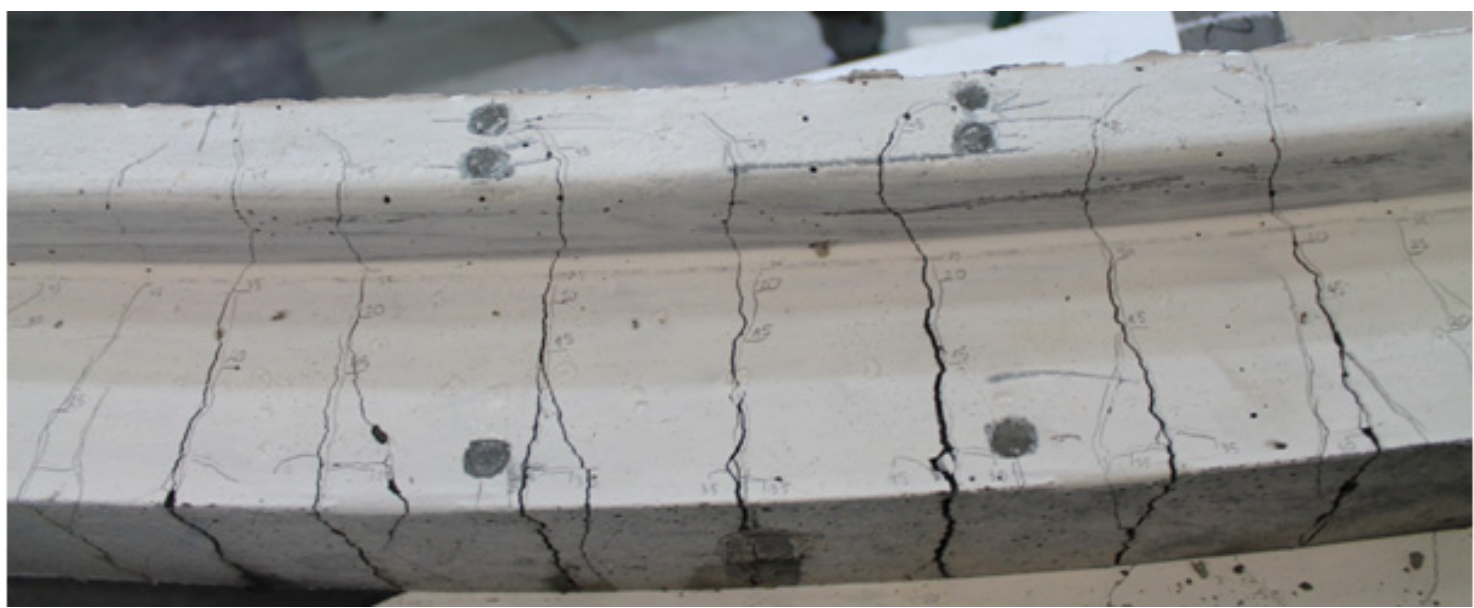

(a)

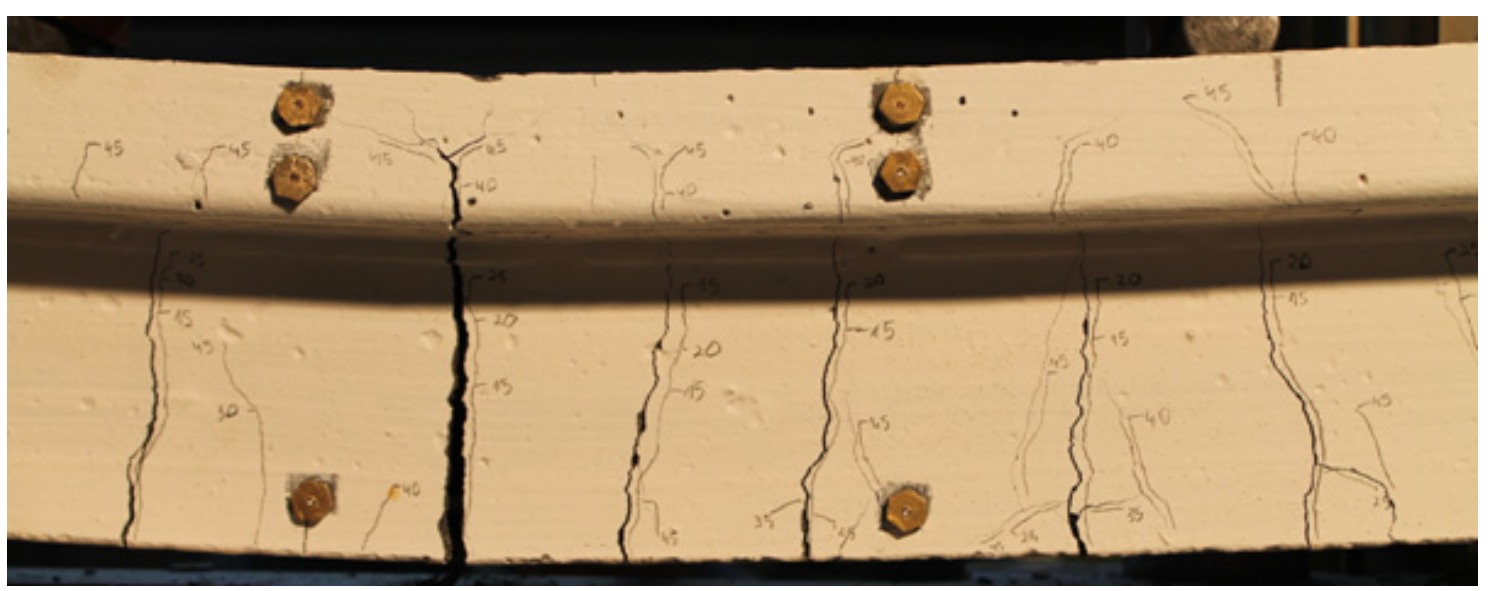

(b)

Figure 11. Crack shaping and development in the test samples: (a) NCAC; (b) RCAC.

Propagation of cracks at different stages was observed by Yang et al. [63]. The authors observed a greater number of cracks at the initial cracking stage in the beams with recycled aggregate (RA), compared to the beams with natural aggregate. This phenomenon was attributed to weaker ITZ and the remains of old adhered mortar on the recycled aggregate. Despite a greater amount of cracks in a RAC beam, the authors observed similar crack propagation both in the concretes with natural and recycled aggregate. The cracks appeared in the flexure zone and then propagated in the compressed zone until beam destruction. Arezoumandi et al. [58], while investigating reinforced concrete beams with recycled aggregate, observed that despite similar morphology and crack propagation, the beams with RA were characterized by smaller distance between cracks on the beam span compared to the beams with natural aggregate. The authors [58] also observed lower rigidity of the beams with RA after cracking moment, which confirms the attainment of lower moduli of elasticity of the concretes with recycled aggregate.

\section{Conclusions}

The study investigated the effect of recycled aggregates from high-strength concretes on the mechanical deformation properties of HPC. The following conclusions can be drawn from the research:

- The concrete made of recycled aggregate is characterized by lower compressive strength in each of the three curing periods (after 7, 14, and 28 days) as well as $26 \%$ lower flexural strength after 28 days. An increase in the compressive strength 
after 28 days was observed in RCAC, compared to NCAC, which may result from the self-hardening phenomenon of the concrete with recycled aggregate.

- The concretes made of recycled aggregate indicated $15 \%$ lower elastic modulus compared to the concretes made of natural aggregate. A strong correlation between the compressive strength and $\mathrm{E}_{\mathrm{cm}, 28}$ was observed. NCAC with higher compressive strength, equal to $127.2 \mathrm{MPa}$, were also characterized by higher modulus of elasticity.

- Reinforced T-beams made of recycled HPC aggregate, were characterized by greater deflection, compared to the concrete made of natural aggregate. When the load of $45 \mathrm{kN}$ was applied, this value was almost 2.5-fold greater than in the case of NCAC.

- The studies indicated a $7.6 \%$ reduction in the flexural bearing capacity of the beams reinforced with recycled aggregate, compared to the T-beam made of natural aggregate. - In the case of the beams with RCA, first cracks appeared earlier than in the beams with natural aggregate. Eventually, all investigated beams exhibited a similar destruction pattern.

Substitution of natural basalt aggregate with high-strength recycled aggregate enables to obtain concrete with high compressive strength and good performance parameters. Taking into account the depletion of natural resources and the emphasis of European Union on sustainable development and waste management, recycled aggregate will be increasingly popular in the construction industry. This will enable decreases both in the usage of natural aggregates, as well as in the costs connected with the processing of wastes.

Author Contributions: Conceptualization, B.S.-B.; Methodology, B.S.-B.; Formal analysis, M.G.-F.; Investigation, B.S.-B.; Writing-original draft preparation, M.G.-F.; Writing-review and editing, M.G.-F.; Supervision, B.S.-B.; Project administration, B.S.-B.; Funding acquisition, B.S.-B. All authors have read and agreed to the published version of the manuscript.

Funding: This work was financially supported by the Ministry of Science and Higher Education, within the 389 statutory, research number WZ/WB-IIL/4/2020.

Institutional Review Board Statement: Not applicable.

Informed Consent Statement: Not applicable.

Data Availability Statement: Not applicable.

Conflicts of Interest: The authors declare no conflict of interest.

\section{References}

1. Kozioł, W.; Ciepliński, A.; Machniak, Ł.; Borcz, A. Aggregates in Construction. In Nowoczesne Budownictwo Inżynieryjne; Nowoczesne Budownictwo Inżynieryjne: Cracow, Poland, 2015; Volume 4, pp. 98-100.

2. Shamili, S.R.; Karthikeyan, J. An Overview of Construction and Demolition Waste as Coarse Aggregate in Concrete. Int. J. Struct. Constr. Eng. 2020, 14, 453-458.

3. Pourkhorshidi, S.; Sangiorgi, C.; Torreggiani, D.; Tassinari, P. Using Recycled Aggregates from Construction and Demolition Waste in Unbound Layers of Pavements. Sustainability 2020, 12, 9386. [CrossRef]

4. Waste Generation, European Commission Eurostat. Available online: https://ec.europa.eu/eurostat/statistics-explained/index. php/Waste_statistics\#Total_waste_generation (accessed on 12 April 2021).

5. Nwakaire, C.M.; Yap, S.P.; Onn, C.C.; Yuen, C.W.; Ibrahim, H.A. Utilisation of recycled concrete aggregates for sustainable highway pavement applications. Constr. Build. Mater. 2020, 235, 117444. [CrossRef]

6. Bai, G.; Zhu, C.; Liu, C.; Liu, B. An evaluation of the recycled aggregate characteristics and the recycled aggregate concrete mechanical properties. Constr. Build. Mater. 2020, 240, 117978. [CrossRef]

7. RILEM Recommendation. Specifications for concrete with recycled aggregates. Mater. Struct. 1994, 27, 557-559.

8. He, S.Y.; Lai, J.X.; Wang, L.X.; Wang, K. A literature review on properties and applications of grouts for shield tunnel. Constr. Build. Mater. 2020, 231, 468-482. [CrossRef]

9. Li, P.L.; Lu, Y.Q.; Lai, J.X.; Liu, H.Q. A comparative study of protective schemes for shield tunneling adjacent to pile groups. Adv. Civ. Eng. 2020, 12, 1874137. [CrossRef]

10. McGinnis, M.J.; Davis, M.; De la Rosa, A.; Weldon, B.D.; Kurama, Y.C. Strength and stiffness of concrete with recycled concrete aggregates. Constr. Build. Mater. 2017, 154, 258-269. [CrossRef]

11. Andrzejuk, W.; Barnat-Hunek, D.; Góra, J. Physical Properties of Mineral and Recycled Aggregates Used to Mineral-Asphalt Mixtures. Materials 2019, 12, 3437. [CrossRef] 
12. Bai, G.L.; Zhu, C.; Liu, C.; Liu, H.W. Chloride ion invasive behavior of recycled aggregate concrete under coupling flexural loading and wetting-drying cycles. KSCE J. Civ. Eng. 2019, 23, 4454-4462. [CrossRef]

13. Suryawanshi, S.R.; Singh, B.; Bhargava, P. Characterization of recycled aggregate concrete. Adv. Struct. Eng. 2015, 1813-1822. [CrossRef]

14. Gokce, A.; Nagataki, S.; Saeki, T.; Hisada, M. Identification of frost-susceptible recycled concrete aggregates for durability of concrete. Constr. Build. Mater. 2011, 25, 2426-2431. [CrossRef]

15. Martín-Morales, M.; Zamorano, M.; Ruiz-Moyano, A.; Valverde-Espinosa, I. Characterization of recycled aggregates construction and demolition waste for concrete production following the Spanish Structural Concrete Code EHE-08. Constr. Build. Mater. 2011, 25, 742-748. [CrossRef]

16. Duan, Z.H.; Poon, C.S. Properties of recycled aggregate concrete made with recycled aggregates with different amounts of old adhered mortars. Mater. Des. 2014, 58, 19-29. [CrossRef]

17. Surendar, M.; Ananthi, G.B.G.; Sharaniya, M.; Deepak, M.S.; Soundarya, T.V. Mechanical properties of concrete with recycled aggregate and $\mathrm{M}$-sand. Mater. Today Proc. 2021. [CrossRef]

18. Martinez-Echevarria, M.J.; Lopez-Alonso, M.; Garach, L.; Alegre, J.; Poon, C.S.; Agrela, F.; Cabrera, M. Crushing treatment on recycled aggregates to improve their mechanical behaviour for use in unbound road layers. Constr. Build. Mater. 2020, $263,120517$. [CrossRef]

19. Belarouf, S.; Samaouali, A.; Gueraoui, K.; Rahier, H. Mechanical Properties of Concrete with Recycled Concrete Aggregates. Int. Rev. Civ. Eng. 2020, 11, 268. [CrossRef]

20. Sadowska-Buraczewska, B. Kruszywa z recyklingu w budownictwie. Inżynieria Ekol. 2014, 40, 74-81. [CrossRef]

21. Ajdukiewicz, A.; Kliszczewicz, A. Influence of recycled aggregates on mechanical properties of HS/HPC. Cem. Concr. Compos. 2002, 24, 269-279. [CrossRef]

22. Gonzales-Corominas, A.; Etxeberria, M. Properties of high performance concreto made with recycled fine ceramic and coarse mixed aggregates. Constr. Build. Mater. 2014, 68. [CrossRef]

23. Zhutovsky, S.; Kovler, K. Influence of water to cement ratio on the efficiency of internal curing of high-performance concrete. Constr. Build. Mater. 2017, 144, 311-316. [CrossRef]

24. Kim, Y.J.; Wang, J. Development of Ultra-High-Performance Concrete with Various Silica Admixtures. ACI Mater. J. 2019, 116, 33-44. [CrossRef]

25. Golewski, G. The Beneficial Effect of the Addition of Fly Ash on Reduction of the Size of Microcracks in the ITZ of Concrete Composites under Dynamic Loading. Energies 2021, 14, 668. [CrossRef]

26. Andreu, G.; Miren, E. Experimental analysis of properties of high performance recycled aggregate concrete. Constr. Build. Mater. 2014, 52, 227-235. [CrossRef]

27. PN-EN 197-1:2012. Cement_Part 1: Composition, Specification and Conformity Criteria for Common Cements; Polish Committee for Standardization: Warsaw, Poland, 2013.

28. PN-B-19707:2013. Cement. Special Cement. Composition, Requirements and Conformity Criteria; Polish Committee for Standardization: Warsaw, Poland, 2013.

29. EN 13263-1:2005. Silica Fume for Concrete-Part 1: Definitions, Requirements and Conformity Criteria; European Committee for Standarization: Brussels, Belgium, 2009.

30. Sadowska-Buraczewska, B.; Barnat-Hunek, D.; Szafraniec, M. Influence of Recycled High-Performance Aggregate on Deformation and Load-Carrying Capacity of Reinforced Concrete Beams. Materials 2020, 13, 186. [CrossRef] [PubMed]

31. Sadowska-Buraczewska, B.; Szafraniec, M.; Barnat-Hunek, D.; Łagód, G. Flexural Behavior of Composite Concrete Slabs Made with Steel and Polypropylene Fibers Reinforced Concrete in the Compression Zone. Materials 2020, 13, 3616. [CrossRef]

32. PN-EN 12390-1:2013-03. Testing Hardened Concrete_Part 1: Shape, Dimensions and Other Requirements for Specimens and Moulds; Polish Committee for Standardization: Warsaw, Poland, 2013.

33. PN-EN 12390-2:2019-07. Testing Hardened Concrete—Part 2: Making and Curing Specimens for Strength Tests; Polish Committee for Standardization: Warsaw, Poland, 2019.

34. PN-EN 12390-3:2019-07. Testing Hardened Concrete Part 3: Compressive Strength of Test Specimens; Polish Committee for Standardization: Warsaw, Poland, 2019.

35. PN-EN 12390-5:2019-08. Testing Hardened Concrete Part 5: Flexural Strength of Test Specimens; Polish Committee for Standardization: Warsaw, Poland, 2019.

36. PN-EN 12390-13:2014-02. Testing Hardened Concrete Part 13: Determination of Secant Modulus of Elasticity in Compression; Polish Committee for Standardization: Warsaw, Poland, 2014.

37. ITB AT-15-4648/2006. Stalowe Pręty Żebrowane BS500S, Do Zbrojenia Betonu; Instytut Techniki Budowlanej: Warsaw, Poland, 2006.

38. Ahmed Shaikh, F.U.; Nath, P.; Hosan, A.; John, M.; Biswas, W.K. Sustainability assessment of recycled aggregates concrete mixes containing industrial by-products. Mater. Today Sustain. 2019, 5, 100013. [CrossRef]

39. Akhtar, A.; Sarmah, A.K. Construction and demolition waste generation and properties of recycled aggregate concrete: A global perspective. J. Clean. Prod. 2018, 186, 262-281. [CrossRef]

40. Zhan, B.; Xuan, D.; Poon, C.S.; Scrivener, K.L. Characterization of interfacial transition zone in concrete prepared with carbonated modeled recycled concrete aggregates. Cem. Concr. Res. 2020, 136, 106175. [CrossRef]

41. Tu, T.Y.; Chen, Y.Y.; Hwang, C.L. Properties of HPC with recycled aggregates. Cem. Concr. Res. 2006, 943-950. [CrossRef] 
42. Li, W.; Xiao, J.; Sun, Z.; Kawashima, S.; Shah, S.P. Interfacial transition zones in recycled aggregate concrete with different mixing approaches. Constr. Build. Mater. 2012, 35, 1045-1055. [CrossRef]

43. Mohammed, N.; Sarsam, K.; Hussien, M. The influence of recycled concrete aggregate on the properties of concrete. MATEC Web Conf. 2018, 162, 02020. [CrossRef]

44. Poon, C.S.; Shui, Z.H.; Lam, L. Effect of microstructure of ITZ on compressive strength of concrete prepared with recycled aggregates. Constr. Build. Mater. 2004, 18, 461-468. [CrossRef]

45. Kou, S.; Poon, C. Effect of the quality of parent concrete on the properties of high performance recycled aggregate concrete. Constr. Build. Mater. 2015, 77, 501-508. [CrossRef]

46. Huoth, P.; Suntharavadivel, T.G.; Duan, K. Effect of silica fume on recycled aggregate concrete. Mater. Sci. 2014, 2, $249-254$.

47. Bostanci, S.C.; Limbachiya, M.; Kew, H. Portland-composite and composite cement concretes made with coarse recycled and recycled glass sand aggregates: Engineering 17and durability properties. Constr. Build. Mater. 2016, 128, 324-340. [CrossRef]

48. Corinaldesi, V.; Moriconi, G. Influence of mineral additions on the performance of $100 \%$ recycled aggregate concrete. Constr. Build. Mater. 2009, 23, 2869-2876. [CrossRef]

49. Wagih, A.M.; El-Karmoty, H.Z.; Ebid, M.; Okba, S.H. Recycled construction and demolition concrete wasteas aggregate for structural concrete. Hous. Build. Natl. Res. Cent. 2013, 9, 193-200. [CrossRef]

50. Neville, A.M. Properties of Concrete, 4th ed.; Wiley: Longman, UK, 2000.

51. Jang, S.J.; Yun, H.D. Mechanical properties of ready-mixed concrete incorporating fine recycled aggregate. Mag. Concr. Res. 2015, 67, 621-632. [CrossRef]

52. Góra, J.; Piasta, W. Impact of mechanical resistance of aggregate on properties of concrete. Case Stud. Constr. Mater. 2020, 13, e00438. [CrossRef]

53. Khan, A.R.; Khan, M.S.; Fareed, S. Shear Behavior of Recycled Aggregate Concrete Beams. In Proceedings of the 10th International Civil Engineering Conference (ICEC-2019), Karachi, Pakistan, 23-24 February 2019.

54. Lapko, A.; Grygo, R. Long term deformations of recycled aggregate concrete (RAC) beams made of recycled concrete. Modern building materials, structures and techniques. In Proceedings of the 10th International Conference, Vilnius, Lithuania, 19-21 May 2010; pp. 367-372.

55. Lapko, A.; Grygo, R. Studies of RC Beams Made of Recycling Aggregate Concrete Strengthened with the HSC-HPC Inclusions. Procedia Eng. 2013, 57, 678-686. [CrossRef]

56. Choi, W.; Yun, H. Long-term deflection and flexural behavior of reinforced concrete beams with recycled aggregate. Mater. Des. 2013, 51, 742-750. [CrossRef]

57. Pacheco, J.; de Brito, J.; Ferreira, J.; Soares, D. Dynamic characterization of full-scale structures made with recycled coarse aggregates. J. Clean. Prod. 2017, 142, 4195-4205. [CrossRef]

58. Arezoumandi, M.; Smith, A.; Volz, J.S.; Khayat, K.H. An experimental study on flexural strength of reinforced concrete beams with 100\% recycled concrete aggregate. Eng. Struct. 2015, 88, 154-162. [CrossRef]

59. Seara-Paz, S.; Gonzalez-Fonteboa, B.; Martinez-Abella, F.; Carro-Lopez, D. Long-term flexural performance of reinforced concrete beams with recycled coarse aggregates. Constr. Build. Mater. 2018, 176, 593-607. [CrossRef]

60. Xiao, J.; Li, J.; Zhang, C. On statistical characteristics of the compressive strength of recycled aggregate concrete. Struct. Concr. 2005, 6, 149-153. [CrossRef]

61. Mukherjee, D.; Chakraborty, S.; Bhattacharya, P.G. A statistical study on compressive strength of recycled concrete. J. Inst. Eng. Civil Eng. Div. 2003, 83, 219-220.

62. Fahmy, M.F.M.; Idriss, L.K. Flexural behavior of large scale semi-precast reinforced concrete T-beams made of natural and recycled aggregate concrete. Eng. Struct. 2019, 198, 109525. [CrossRef]

63. Yang, I.H.; Park, J.; Kim, K.C.; Lee, H. Structural Behavior of Concrete Beams Containing Recycled Coarse Aggregates under Flexure. Adv. Mater. Sci. Eng. 2020. [CrossRef] 